\title{
Chlorine Dioxide as a Disinfectant for Ralstonia solanacearum Control in Water, Storage and Equipment
}

\author{
Tatjana Popović ${ }^{1}$ Žarko Ivanović ${ }^{1}$ Sanja Janjatović ${ }^{2}$ \\ Maja Ignjatov ${ }^{3}$. Predrag Milovanović ${ }^{4}$ \\ ${ }^{1}$ Institute for Plant Protection and Environment, Teodora Drajzera 9, 11000 Belgrade, Serbia \\ ${ }^{2}$ Deka inžinjering, Andre Nikolića 1-3, 11000 Belgrade, Serbia \\ ${ }^{3}$ Institute of Field and Vegetable Crops, Maksima Gorkog 30, 21000 Novi Sad, Serbia \\ ${ }^{4}$ Galenika-Fitofarmacija a.d., Batajnički drum bb, 11080 Belgrade-Zemun, Serbia
}

\begin{abstract}
Summary: Brown rot or bacterial wilt caused by bacterium Ralstonia solanacearum is the main limiting factor in potato production. Quarantine measures are necessary to avoid spread of disease to disease-free areas. R. solanacearum has been shown to contaminate watercourses from which crop irrigation is then prohibited causing further potential losses in yield and quality. The bacteria also spread via surfaces that diseased seed potatoes come into contact with. This study showed bactericidal activity of chlorine dioxide $\left(\mathrm{ClO}_{2}\right)$ on $\mathrm{R}$. solanacearum for disinfection of water, surface and equipment. The results showed that $\mathrm{ClO}_{2}$ solution at concentration of $2 \mathrm{ppm}$ at 30 minutes of exposure time had bactericidal effect for disinfection of water. For surface and equipment disinfection, concentration of 50 ppm showed total efficacy at $30 \mathrm{~min}$ and $5 \mathrm{sec}$ exposure time, respectively. Results suggest that use of $\mathrm{ClO}_{2}$ as a disinfectant has a potential for control of brown rot pathogen in water, storage and equipment.

Key words: bactericides, chlorine, disinfection, equipment, potatoes, Ralstonia solanacearum, rots, surfaces, waters
\end{abstract}

\section{Introduction}

Ralstonia solanacearum, the causal agent of potato brown rot (Figure 1) or bacterial wilt, is the main limiting factor in potato production in many parts of the world (Janse, 1996; Elphinstone, 2001). The bacterium is classified as a quarantine organism in the EU legislation. Therefore, adequate control measures must be taken to prevent its spread. So far the pathogen has been reported in Portugal, Italy, Greece, Spain, Cyprus, Sweden, Belgium, the Netherlands, France, Austria, Turkey and England (EPPO/CABI, 1996). In Serbia, R. solanacearum was confirmed in 2011 in 7 samples of ware potato tubers in Bačka Districts (MilijaševićMarčić et al., 2013).

Potato equipment and storages are exposed to a number of pests, including fungi, bacteria, insects, nematodes, and weed seeds. Many of these pests can be spread from one tuber to another or field to field on equipment or in storage, and cause problems in future crops if not eliminated or at least minimized (Olsen \& Nolte, 2011). Brown rot pathogen is mainly disseminated in latently infected seed, as well as through infected

Corresponding author:

tanjaizbis@gmail.com

\section{Acknowledgement:}

This study is a part of the Project No. III43010 funded by Ministry of Education, Science and Technological Development, Republic of Serbia. early ware potatoes, soil or farm equipment (EPPO/ CABI, 1996; Hong, 2005; Janse, 2005). The bacterium has the ability to survive in aquatic environments, being able to multiply in pure water in the absence of nutrients (Wakimoto et al., 1982) and may be spread to other hosts when contaminated surface water is used for irrigation. A number of weeds were found as hosts of bacteria often in a form of latent infection. In Europe, the most frequently reported are Solanum dulcamara, a common perennial semi-aquatic weed inhabiting river banks, Solanum nigrum and Urtica dioica (Wenneker et al., 1999).

Control of $R$. solanacearum is a difficult strategy based on the use of healthy, disease-free certified seed, resistant or tolerant potato varieties, $R$. solanacearum-free soil, control in industrial potato washings by heat, anaerobic digestion, filtration, oxidation or UV irradiation (Elphinstone \& Harris, 2002), rotation with non-host plants (such as grasses), control of weed hosts and volunteer plants, good hygiene practices (regular cleaning and disinfection of machinery, equipment, containers and storage facilities), and root-knot nematode control (Janse, 2005; OEPP/ EPPO, 2006, 2011; Champoiseau et al., 2009).

One of the best methods to minimize spread of disease is a good sanitation program for machinery, equipment and storage facilities during cutting tubers and handling. Cleaning and disinfection procedures are obligatory where quarantine disease brown rot is found, because all machines, materials and equipment that come into contact with infected potato material can become 
contaminated with the bacteria and subsequently act as a potential source of further infection (OEPP/EPPO, 2006). Storage cleaning and disinfection is important, especially to minimize disease carryover from one season to the next (Olsen \& Nolte, 2011). Based on OEPP/EPPO (2006) list, the following disinfectants can be used in potato production: aldehyde-based, ammonia solution, chlorinebased, chlorinated phenol-based, chloramide compound, iodine based, organic acid, peroxide/peroxygen based, quaternary ammonium, triazin-based, and sodium hydroxide. This range of chemicals is used in different brands produced by different manufacturers. Commercial products can vary in percentage of active ingredient, allowable application rates, and whether or not the product is labeled for potato storages and handling equipment.

Chlorine dioxide $\left(\mathrm{ClO}_{2}\right)$ is a disinfectant which possesses high efficiency in reducing many microorganisms, fast, broad sterilization ability and low toxicity for the environment ( $\mathrm{YaO}$ et al., 2010). The application and efficacy of $\mathrm{ClO}_{2}$ in agriculture needs further evaluation. According to Reybrouck (1998) the basic principle of disinfectant tests is that the antimicrobial efficiency of a disinfectant is examined at three stages of testing: the first concerns laboratory tests where it is verified whether a chemical compound or a preparation possesses antimicrobial activity; in the second stage, disinfection procedures are examined and it is determined under which conditions and at which use-dilution for a given application the preparation is active, and the third stage takes place in the field, and comprises the in-loco or insitu tests. In this study we applied laboratory tests to evaluate bactericidal activity of $\mathrm{ClO}_{2}$ against $\mathrm{R}$. solanacearum in water, surface (concrete-like material) and equipment (cutting knives).

\section{Material and Methods}

\section{Preparation of bacterial strain and $\mathrm{ClO}_{2}$ solution}

Chlorine dioxide solution was provided in product TwinOxide-Eco Winners (0.3\% stock solution) (http:// www.twinoxide.co.rs/twinoxide.html). R. solanacearum reference strain PD2762 (=CFBP 3857) was obtained from French collection of plant pathogenic bacteria (La

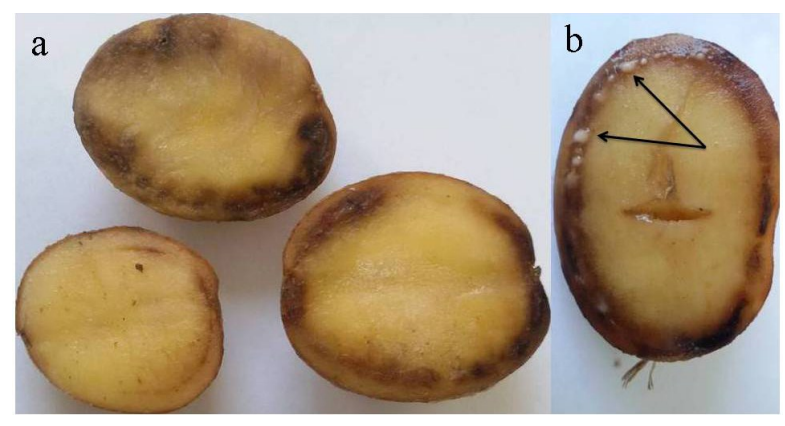

Figure 1. Ralstonia solanacearum; infection of potato tubers a) brownish discoloration of the vascular ring, b) bacterial exudate from vascular ring
Collection Française de Bactéries Phytopathogènes, France) and used in all tests. The strain was grown on Yeast peptone glucose agar (YPGA) at $28^{\circ} \mathrm{C}$ for $48 \mathrm{~h}$. The bacterial concentration was adjusted to the final concentration $\left(10^{8}\right.$ cells $\left.\mathrm{mL}^{-1}\right)$ using densitometer (DEN1B, Biosan). All experiments were performed in three replications.

\section{Water disinfection}

A method described by Kelaniyangoda et al. (1996, 1997) and Reybrouck (1998) was used. Efficacy of $\mathrm{ClO}_{2}$ was tested at concentrations of 1 and 2 ppm. $100 \mathrm{ml}$ of bacterial suspension of $R$. solanacearum was mixed with the tested concentration of the product. After the exposition time of 15 and $30 \mathrm{~min}$ mixture was plated on YPGA culture medium. Sterile distillated water was used as a negative control, and pure untreated bacterial suspension served as a positive control. The plates were incubated at $28{ }^{\circ} \mathrm{C}$ for three days.

\section{Surface disinfection}

For this purpose we used a modified method described by Dowlut \& Judd (2012). Efficacy of the product was tested at concentration of $50 \mathrm{ppm}$. Sterile tiles $15 \mathrm{~cm}$ x $15 \mathrm{~cm}$ (concrete-like material) were inoculated by spraying with bacterial suspension of $R$. solanacearum. The tiles were allowed to dry for one hour at room temperature $\left(\approx 20^{\circ} \mathrm{C}\right)$. After drying, tiles were sprayed with $\mathrm{ClO}_{2}$ in tested concentrations. After exposition time of 10, 30, and $60 \mathrm{~min}$, tiles were carefully swabbed with a sterile pre-moistened swab (in sterile phosphate buffer). The swab was then immersed into $1 \mathrm{ml}$ sterile phosphate buffer and $100 \mu \mathrm{l}$ of that resulting suspension was plated on YPGA culture media. Swabs taken from non-inoculated tiles were used as a negative control, and swabs taken from inoculated untreated tiles were used as positive control. The plates were incubated at $28^{\circ} \mathrm{C}$.

\section{Equipment disinfection}

Method that was used for this purpose is described by Celar et al. (2007). Efficacy of $\mathrm{ClO}_{2}$ was tested at concentration of $50 \mathrm{ppm}$. Sterile scalpel was first dipped in the bacterial suspension of $R$. solanacearum, and then instantly put immersed in the dilution of the product, for a pre-specified time $1,5,10$, and $20 \mathrm{sec}$. After disinfection time, cuts were made in sections of $3 \times 3$ cuts $(\approx 5 \mathrm{~cm})$ on YPGA culture media. The scalpel was flamed sterilized and re-dipped before cutting into a new section. Sterile distillated water and pure bacterial suspension were used as negative and positive controls, respectively. The plates were incubated at $28^{\circ} \mathrm{C}$.

\section{Experiments evaluation}

Growth of bacterial colonies was observed in the following 24-48 hours and compared with control treatments. Results were recorded after $48 \mathrm{~h}$ and expressed as 'growth' (+), 'reduced growth' (+-) or 'no growth' (-). 


\section{Results and Discussion}

\section{Water disinfection}

The results showed that $\mathrm{ClO}_{2}$ solution at concentration of $2 \mathrm{ppm}$ and 30 minute of exposure time inhibited $R$. solanacearum growth in water (Table 1). Lower concentration tested (1 ppm) showed bactericide influence but allowed growth (of bacterial colonies in deacrease number compared with positive control).

In order to validate potential disinfection measures in control R. solanacearum for irrigation water or industrial potato washings, Elphinstone (2001) stated a series treatment specifications established under laboratory conditions: pasteurization, UV irradiation, ozonation, chlorination and peracetic acid dosing trialled under commercial conditions. Author suggests that river water should be dosed with chlorine dioxide to achieve a residual chlorine dioxide concentration of at least $0.1 \mathrm{mg}$ per L, measurable over a minimum period of $2 \mathrm{~min}$. Kelaniyangoda et al. $(1996,1997)$ investigated the feasibility of using chlorine (calcium hypochlorite- $33 \%$ chlorine) to sterilize the irrigation water against $R$. solanacearum. The results showed that treatment with $2 \mathrm{ppm}$ for $6 \mathrm{~h}$ or 2.75 ppm for $1 \mathrm{~h}$ completely sterilized the water. Yao et al. (2010) evaluated disinfection application of $\mathrm{ClO}_{2}$ solution on phytopathogenic bacteria including Eminia carotovora subsp. carotovora and R. solancearum in irrigation water showing that $\mathrm{ClO}_{2}$ solution at $1.3 \mathrm{mg} \mathrm{L}^{-1}$ could inhibit the growth of tested bacteria.

\section{Surface disinfection}

Application of $\mathrm{ClO}_{2}$ in tested concentration of $50 \mathrm{ppm}$ at exposure time of 30 and $60 \mathrm{~min}$ showed total efficacy for surface disinfection against R. solanacearum (Table 1). After $10 \mathrm{~min}$ exposition time significant reduction in number of bacterial colonies was observed when compared with positive control.

Some authors (Olsen \& Nolte, 2011; Jayanty, 2012) recommended list of commonly used disinfectants for potato handling equipment and storage structures: hypochlorites (sodium hypochlorite, calcium hypochlorite, ammonium hypochlorite), chlorine dioxide, copper quinolinolate, quaternary ammonium, hydrogen peroxide and/or peroxyacetic acid mixtures. If using chlorine-based compounds, the solution needs to be buffered to a $\mathrm{pH}$ of 6.0 to 7.5 for maximum effectiveness. Authors also cited that one of the most important points to follow is to keep surfaces wet with disinfectant solution for a minimum of 10 to 15 minutes, then close the storage for 2 weeks and open up storage to air out and dry the storage surfaces.

\section{Equipment disinfection}

Results of dipping handling equipment into $\mathrm{ClO}_{2}$ in tested concentration of $50 \mathrm{ppm}$ and exposition time at 5, 10, and $20 \mathrm{sec}$ showed total bactericidal activity against $R$. solanacearum (Table 1 ). At exposition time of 1 sec, $\mathrm{ClO}_{2}$ showed partial bactericidal activity but bacterial colonies were formed in deacreased number comparing with positive control.

Cleaning and disinfecting field and handling equipment is related to a seed cutter and pick-style planting equipment (Olsen \& Nolte, 2011). A seed cutter is a common source of contamination for bacterial rot pathogens, because the cutting blades are in continuous use during the cutting process transmitting sap, debris, and the associated pathogens from infected seed tubers to healthy ones. When disinfecting solutions are used for dipping knives, crates, picking baskets or foot dip tanks, the solution should be changed frequently to avoid neutralization (Franc, 2002). According to Franc (2002) and Jayanty (2012), products such as chlorine-based solutions (sodium hypochlorite, calcium hypochlorite and chlorine bleach) and copper sulfate can be used for disinfesting surfaces and potato handling equipment.

\section{Conclusion}

Based on the results of laboratory tests presented in this study, $\mathrm{ClO}_{2}$ could be recommended for use in disinfection of waste water, storage, tools and equipment for control of $R$. solanacearum with recommended concentrations of $2 \mathrm{ppm}$ for water disinfection, at minimum $30 \mathrm{~min}$ of exposure time and $50 \mathrm{ppm}$ for storage and equipment disinfection, at minimum $30 \mathrm{~min}$ and $5 \mathrm{sec}$ of exposure time, respectively.

Table 1. Bactericidal activity of chlorine dioxide against Ralstonia solanacearum in water, surface and equipment

\begin{tabular}{|c|c|c|c|c|c|c|c|c|c|}
\hline \multirow{3}{*}{ Concentration } & \multirow{2}{*}{\multicolumn{2}{|c|}{$\frac{\text { Water disinfection }}{\text { Exposition time }}$}} & \multicolumn{3}{|c|}{ Surface disinfection } & \multicolumn{4}{|c|}{ Equipment disinfection } \\
\hline & & & \multicolumn{3}{|c|}{ Exposition time } & \multicolumn{4}{|c|}{ Exposition time } \\
\hline & $15 \mathrm{~min}$ & $30 \mathrm{~min}$ & $10 \mathrm{~min}$ & $30 \mathrm{~min}$ & $60 \mathrm{~min}$ & $1 \mathrm{sec}$ & $5 \mathrm{sec}$ & $10 \mathrm{sec}$ & $20 \mathrm{sec}$ \\
\hline $50 \mathrm{ppm}$ & $\mathrm{nt}$ & $\mathrm{nt}$ & +- & - & - & +- & - & - & - \\
\hline $2 \mathrm{ppm}$ & +- & - & $\mathrm{nt}$ & $\mathrm{nt}$ & $\mathrm{nt}$ & $\mathrm{nt}$ & nt & $\mathrm{nt}$ & $\mathrm{nt}$ \\
\hline $1 \mathrm{ppm}$ & +- & +- & nt & nt & nt & nt & nt & nt & nt \\
\hline Positive control & + & + & + & + & + & + & + & + & + \\
\hline Negative control & - & - & - & - & - & - & - & - & - \\
\hline
\end{tabular}

Legend: - no bacterial colonies; +- reduced number of bacterial colonies; + normal growth of bacterial colonies; nt not tested 


\section{References}

Celar, F., Valic, N., Kosmelj, K., \& Gril, T. (2007). Evaluating the efficacy, corrosivity and phytotoxicity of some disinfectants against Enwinia amylovora (Burrill) Winslow et al. using a new statistical measure. Journal of Plant Diseases and Protection, 114(2), 49-53.

Champoiseau, P. G., Jones, J. B., \& Allen, C. (2009). Ralstonia solanacearum race 3 biovar 2 causes tropical losses and temperate anxieties. Online. Published 13 March 2009. Plant Health Progress. doi:10.1094/PHP-2009-0313-01-RV

Dowlut, S., \& Judd, M. (2012). Disinfectant efficacy testing. VLS Project No: E2012-04. http://www.kvh.org.nz/vdb/document/91123

Elphinstone, J. G. (2001). Monitoring and control of the potato brown rot bacterium (Ralstonia solanacearum) in the UK: A case study. Proceedings of the FNK/EAPR/ESA/UEITP 2nd European Potato Processing Conference. Lausanne, Switzerland, 14-15 ${ }^{\text {th }}$ November.

Elphinstone, J., \& Harris, R. (2002). Monitoring and control of the potato brown rot bacterium in irrigation water. British Potato Council report 190. http://www.potato.org.uk/upload/pdf/ researchReports/ report190.pdf.

EPPO/CABI (1996). Ralstonia solanacearum. In: Quarantine pests for Europe. 2nd edition (Ed. by Smith, I.M.; McNamara, D.G.; Scott, P.R.; Holderness, M.). CAB International, Wallingford, UK,.

Franc, G. D. (2002). Disinfecting Potato Storages and Equipment. High Plains IPM Guide, a cooperative effort of the University of Wyoming, University of Nebraska, Colorado State University and Montana State University.

Hong, J. C. (2005). Detection of Ralstonia solanacearum in irrigation ponds and semiaquatic weeds, and its chemical treatment in water. $\mathrm{PhD}$. Thesis, University of Florida.

Janse, J. D. (1996). Potato brown rot in Western Europe -history, present occurrence and some remarks on possible origin, epidemiology and control strategies. Bulletin OEPP/EPPO Bulletin, 26, 679-695.
Janse, J. D. (2005). Phytobacteriology, principles and practice. Wallingford: CABI Publishing.

Jayanty, S. (2012). Potato Storage Sanitation. Spud Items, 63, 9.

Kelaniyangoda, D. B., Tharmarajah, S. K. \& Herath, L. G. 1996 \& 1997). Bacterial Wilt (Ralstonia solanacearum E.F. Smith) Management in Potato Rooted Stem Cuttings in the Net-house. Tropical Agriculturist, 151.

Milijašević-Marčić, S., Todorović, B., Potočnik, I., Rekanović, E., Stepanović, M., Mitrović, J., \& Duduk, B. (2013): Ralstonia solanacearum - a New Threat to Potato Production in Serbia. Pestic. Phytomed. 28(4), 229-237.

OEPP/EPPO (2006). Disinfection procedures in potato production PM 10/1 (1). OEPP/EPPO Bulletin, 36, 463-466.

OEPP/EPPO (2011). Ralstonia solanacearum PM 9/3 (2). OEPP/EPPO Bulletin, 41, 389-393.

Olsen, N., \& Nolte, P. (2011). Cleaning and Disinfecting Potato Equipment and Storage Facilities. University of Idaho Extension CIS 1180. Moscow, ID: University of Idaho Extension. http:// www.cals.uidaho.edu/edComm/pdf/CIS/CIS1180.pdf.

Reybrouck, G. (1998). The testing of disinfectants. International Biodeterioration \& Biodegradation, 41, 269-272.

Twin Oxide-RS (2013). Technical documentation of product. Retrieved from www.twinoxide.co.rs

Wakimoto, S., Utatsu, I., Matsuo, N., \& Hayashi, N. (1982). Multiplication of Pseudomonas solanacearum in pure water. Ann. Phytopath. Soc. Japan, 48, 620-627.

Wenneker, M, Verdel, M. S. W., Groeneveld, R. M. W., Kempenaar, C., van Beuningen, A. R., \& Janse, J. D. (1999). Ralstonia (Pseudomonas) solanacearum race 3 (biovar 2) in surface water and natural weed hosts: first report on stinging nettle (Urtica dioica). Eur. J. Plant Pathol. 105(3), 307-315.

Yao, K. S., Hsieh, Y. H., Chang, Y. J., Chang, C. Y., Cheng, T. C., \& Liao, H. L. (2010). Inactivation effect of chlorine dioxide on phytopathogenic bacteria in irrigation water. J. Environ. Eng. Manage 20(3), 157-160.

\section{Hlor-dioksid kao dezinficijens za kontrolu Ralstonia solanacearum u vodi, skladištu i opremi}

\section{Tatjana Popović · Žarko Ivanović · Sanja Janjatović · Maja Ignjatov · Predrag Milovanović}

Sažetak: Mrka trulež ili bakteriozna uvelost krompira prozrokovana bakterijom Ralstonia solanacearum ograničavajući je faktor uspešne proizvodnje krompira. Sprovođenje karantinskih mera zaštite je neophodno kako bi se izbeglo širenje bakterije u regione u kojima bolest nije prisutna. S obzirom da R. solanacearum može kontaminirati vodene tokove i izvore koji služe za navodnjavanje useva, zabrana korišćenja dovodi do dodatnih potencijalnih gubitaka u prinosu i kvalitetu krompira. Bakterija takođe kontaminira površine sa kojima zaraženi semenski krompir dolazi u dodir. U ovom radu prikazana je baktericidna aktivnost hlor-dioksida $\left(\mathrm{ClO}_{2}\right)$ na bakteriju $\mathrm{R}$. solanacearum u cilju dezinfekcije vode, površine $\mathrm{i}$ opreme. Dobijeni rezultati pokazuju da $\mathrm{ClO}_{2}$ ispoljava baktericidni efekat za dezinfekciju vode u koncentraciji od $2 \mathrm{ppm}$ nakon 30 minuta ekspozicije, za dezinfekciju površine u koncentraciji $50 \mathrm{ppm}$ nakon 30 minuta ekspozicije i za dezinfekciju opreme u koncentraciji 50 ppm nakon 5 sekundi ekspozicije. Rezultati dobijeni u ovom radu ukazuju da $\mathrm{ClO}_{2}$ poseduje potencijal kao dezinficijens za kontrolu prouzrokovača mrke truleži krompira u vodi, skladištu i opremi.

Ključne reči: baktericid, dezinfekcija, hlor, krompir, oprema, površine, Ralstonia solanacearum, trulež, voda 